\title{
Regulatory efficiency and Free Trade in SAARC: Implications on impacts of OBOR on SAARC Trade
}

\author{
Kasuni Ranasinghe ${ }^{1,}$ Priyanga Dunusinghe ${ }^{2}$,Athula Ranasinghe ${ }^{3}$ \\ ${ }^{1}$ Assistant Lecturer, Faculty of Graduate Studies, University of Colombo. \\ ${ }^{2}$ Senior Lecturer, Department of Economics, University of Colombo. \\ ${ }^{3}$ Professor in Economics, Department of Economics, University of Colombo.
}

\begin{abstract}
Transportation is a strong factor in terms of economic development. As well as also having a great influence on regional integration. South Asia has a rich history of trade through sea. Thus ports constitute important economic activities in the region. This paper mainly exposes the role of the efficiency of harbors in trade performances. An extended version of gravity model is used to analyze the correlation of transport infrastructure and exports of South Asia. For the purpose of analysis in this paper, all eight South Asian countries are identified as exporters and selected 25 countries as the partnering countries. Estimated results show that the distance between two countries has negative impact on trade. Country size measured in terms of GDP has positive effect on trade. It is also observed that the compliance time in both reporting country as well as the partner country has a significant influence on trade. Higher compliance time discourages trade. Based on this finding, this study explores the impacts of OBOR on SAARC trade. It is anticipated that the OBOR expands trade through its impact on reducing compliance time.
\end{abstract}

Key Words: Harbor efficiency, SAARC Economic Integration, OBOR, Gravity Model

\section{Introduction}

This paper explores one of the non-conventional determinants of international trade. Namely the relationship between exports and efficiency in trade measured in terms of compliance time to trade regulations. This study assumes that the compliance time is determined by three factors; trade regulations, level of good governance and technological innovations. More stringent regulations and corrupted be bureaucratic practices increase compliance time and more efficient technological innovations reduce the compliance time. Higher compliance time is identified as a deterrent for free trade. Therefore, it is postulated that the compliance time and volume of trade are negatively correlated. An extended gravity model is estimated using compliance time of export country and partner country as determinants of export from SAARC regional countries. 
FGS - CJMR Colombo Journal of Multi - Disciplinary Research

For modeling purposes, only SAARC countries are selected as exporters with 25 partner countries including also SAARC countries.

Findings of this study are interpreted in the context of emerging One Belt One Road (OBOR) initiative. More specifically, it is assumed that the OBOR investments on transport will increase efficiency of world trade by reducing time and cost of transport of goods from one country to another country for the purpose of the analysis in this study. As a result of reduced time and cost trade is encouraged. In order to capture the effect of increased transportation efficient, gravity model is estimated with transportation efficiency as an explanatory variable in the gravity model.

\section{The Model}

Tinbergen invented the gravity model to determine the relationship between bilateral trade and GDP, distance, border and other factors that affect the trade flow. Initially, this concept is based on the Newton's law of gravity. Thus the stranded model estimated that trade between countries is proportional to the gross domestic product of both countries while inversely relate to the distance. However, the theoretical equation of the model is developed over time. Following the method adopted according to the original work of Tinbergen (1962) and Anderson (1979), initial model of gravity model is specified as follows ${ }^{1}$.

$\ln E_{i j}=\alpha+\beta \ln D_{i j}+\lambda_{1} \ln Y_{i}+\lambda_{2} \ln Y_{j}+\lambda_{3} \ln P_{i}+\lambda_{4} P_{j}+\varepsilon_{i j}$

Where, $\mathrm{E}_{\mathrm{ij}}$ stands for Exports from country $i$ to $j, \mathrm{D}_{\mathrm{ij}}$ represents Distance from country $i$ to country $j . \mathrm{Y}_{\mathrm{i}}$ and $\mathrm{Y}_{\mathrm{j}}$ in the model represent GDP of export country and GDP of import country respectively and $\mathrm{P}_{\mathrm{i}}$ and $\mathrm{P}_{\mathrm{j}}$ represent population of two countries. According to Newton's principle gravity is mainly depends on 2 factors; Distance between the two objects and their size. Closer the distance and larger in size the two objects are strongly attached to each other. Following this theory, Tinbergen (1962) used it to describe bilateral trade pattern of the world where, distance is measured in terms of distance between two countries and size is measured in terms of size of the economy. In the literature, size of the economy is measured in terms of several variables such as GDP,

\footnotetext{
${ }^{1}$ At the estimation stage Population variables were dropped due to heavy multicolinearity problem.
} 


\section{Regulatory efficiency and Free Trade in SAARC: Implications on impacts of OBOR on SAARC Trade}

Population and Land area. According to Newton theory and Tinbergen interpretation in trade context, Distance should have negative impact on trade and all the size variables should have positive impact. Therefore, in the above equation, $\beta$ is negative and all $\Lambda \mathrm{s}$ are positive.

Following the conceptual framework, in order to capture the effect of compliance cost on trade two variables are identified; Tine to handle container and Cost to handle a container. Adding the two variables to the initial gravity model following equation is defined.

$$
\ln E_{i j}=\alpha+\beta \ln D_{i j}+\lambda_{1} \ln Y_{i}+\lambda_{2} \ln Y_{j}+\lambda_{3} \ln P_{i}+\lambda_{4} P_{j}+\delta_{1} \ln T_{i}+\delta_{2} \ln T_{j}+\varepsilon_{i j}
$$

According to this equation, whether compliance cost affects trade negatively is measured by the size and sign of two $\delta$ coefficients of the equation (2). It is anticipated that the two $\delta$ coefficients are negative and statistically significant.

Equation (2) within the given theoretical context is sufficient to have a general understanding about the effect of regulations on trade. We are also interested in identifying the effects of trade compliances on trade between SAARC countries. In this model it is captured in terms of a dummy interactive term of $\ln \mathrm{T}_{\mathrm{i}}$ and $\ln \mathrm{T}_{\mathrm{j}}$ variables with dummy representing SAARC countries.

For the purpose of the analysis in this research only SAAR member countries are selected as Export countries. Import countries comprises with all SAARC countries and other countries with significant trade (import from SAARC) with SAARC.

\section{Descriptive Statistics and Correlation Matrix}

This section of the paper report key descriptive statistics of the variables used for the purpose of the analysis. Table 1 presents the regional composition of volume of imports from SAARC countries. 
FGS - CJMR Colombo Journal of Multi - Disciplinary Research

Table 1: Trade Performance of SAARC

\begin{tabular}{llllll}
\hline & 2009 & 2013 & 2015 & 2016 & $\begin{array}{l}\text { Overall } \\
\text { Growth }\end{array}$ \\
\hline SAARC & 264 & 548 & 557 & 677 & 0.13 \\
ASEAN & 781 & 1,507 & 1,004 & 1,297 & 0.07 \\
USA & 4,622 & 8,849 & 8,830 & 12,055 & 0.14 \\
EU & 1,367 & 2,411 & 2,362 & 2,504 & 0.09 \\
OPEC & 1,509 & 2,552 & 2,084 & 2,879 & 0.09 \\
Unclassified & 287 & 762 & 492 & 801 & 0.15 \\
Overall & 909 & 1,687 & 1,441 & 1,822 & 0.10 \\
\hline
\end{tabular}

Source: Author, Based on World Integrated Trade Solution

First row of Table 1 represents average export within SAARC region. Other rows represent the SAARC exports to countries belong other regional cooperation or regional blocks. However, it should be noted that the data representing other regional blocs do not represent the entire block due to the selection process for this study. For this exercise only the countries with significant volume of exports from SAARC countries are selected. For example, from the European Union only two countries are in this sample (The UK and Germany) $)^{2}$. Statistics shown in Table 1 indicate that the USA, the EU and the OPEC have become the most significant export destinations for the SAARC on average.

Table 2 presents the correlation among the variables used in this exercise.

Where, $\mathrm{E}$ is the value of Export, D is the Distance between reporting country (exporter) and partner country (importer) ${ }^{3}$. $\mathrm{X}$ variables measure attributes of partner countries and $\mathrm{Z}$ variables measure the same attributes of reporting countries. Subscripts 1, 2 and 3 are respectively representing GDP, Population and Time to import (export). This is the estimated time required to comply with all procedures required to import (export) goods. Time is measured in terms of days.

First column of the table shows correlation coefficient between the dependent variable and independent variables.

\footnotetext{
${ }^{2}$ For this study only countries to which SAARC exports in significant volumes are included.

${ }^{3}$ Distance is measured in KMs.
} 


\section{Regulatory efficiency and Free Trade in SAARC: Implications on impacts of OBOR on SAARC Trade}

These correlation coefficients represent partial relation between the dependent variable and independent variables.

Table 2: Correlation Matrix

\begin{tabular}{l|lllll|lll}
\multicolumn{2}{c}{$\ln E$} & $\ln D$ & $\mathrm{X}_{1}$ & $\mathrm{X}_{1}$ & $\mathrm{X}_{3}$ & $\mathrm{Z}_{1}$ & $\mathrm{Z}_{2}$ & $\mathrm{Z}_{3}$ \\
\hline $\ln \mathrm{n}$ & 1.00 & & & & & & & \\
$\mathrm{lnD}$ & 0.04 & 1.00 & & & & & & \\
$\mathrm{X}_{1}$ & 0.29 & 0.62 & 1.00 & & & & & \\
$\mathrm{X}_{2}$ & 0.21 & 0.18 & 0.73 & 1.00 & & & & \\
$\mathrm{X}_{3}$ & -0.18 & -0.46 & -0.47 & 0.09 & 1.00 & & & \\
\hline $\mathrm{Z}_{1}$ & 0.70 & -0.04 & -0.13 & -0.12 & 0.10 & 1.00 & & \\
$\mathrm{Z}_{2}$ & 0.63 & -0.08 & -0.15 & -0.11 & 0.13 & 0.96 & 1.00 & \\
$\mathrm{Z}_{3}$ & -0.50 & 0.15 & 0.00 & 0.11 & 0.03 & -0.55 & -0.31 & 1.00 \\
\hline
\end{tabular}

Source: Calculated using World Bank Data

All other cells represent the linear relationship between explanatory variables. Higher correlation between explanatory variables is identified as the multicolinearity problem. Correlation matrix above shows that there are high correlation between Distance $(\mathrm{lnD})$ and GDP of importing country $\left(\mathrm{X}_{1}\right)$, GDP and Population of importing country $\left(\mathrm{X}_{2}\right)$ and GDP of exporting country $\left(Z_{1}\right)$ and Population of exporting country $\left(Z_{2}\right)$. Whether the level of multicolinearity is at harmful level can be determined on the VIF (Variance Inflation Factor $)^{4}$.

\section{Model Estimation}

Table 3 presents the regression results of Gravity model. The model is estimated at three levels. First the Base Gravity model is presented. This includes only the key variables prescribed in literature.

Second model has included the log value of cost of container handling in SAARC countries. The third model introduces interactive terms of log Cost with two regional cooperation dummies (SAARC and ASEAN).

${ }^{4} V I F_{k}=\frac{1}{1-R_{k}^{2}}$. Where, $\mathrm{VIF}_{\mathrm{k}}$ is the Variance Inflation Factor (VIF) of $\mathrm{k}^{\text {th }}$ explanatory variable and $\mathrm{R}_{\mathrm{k}}$ is the multiple correlation of $\mathrm{k}^{\text {th }}$ explanatory variable with other explanatory variables. The rule of thumb is that the VIF greater than 4 is alarming. 
FGS - CJMR Colombo Journal of Multi - Disciplinary Research

In terms of adjusted $\mathrm{R}^{2}$ and $\mathrm{F}$ stats all the models are good in terms of their explanatory power. All the models explain over 50 percent of total variation of the dependent variable. The Root MSE is around 2 for all the models. The Root MSE is a measure of efficiency and unbiasedness of the models. It is stable around some value across all the models indicate that with the changes of model unbiasedness and efficiency are unaffected.

All the t-values are greater than 2 indicating that all the egression coefficients are statistically significant and all VIF values are less than 4. This indicates that the multicolinearity problem is not at serious level ${ }^{5}$.

All the key variables in Base Gravity model are with expected signs. Distance between two countries discourages export. This indicates that on average more trade takes place between close by countries. Log GDP of reporting country (exporter) and partner country (importer) show positive correlation. These variables measure the distance and size effects on gravity. This is consistent with Newton's principle and all the empirical estimates of gravity model.

In addition to the base variables of gravity model, two more variables are added to Model 2. Namely, Time to comply with export procedures in exporting country and Time to comply with import procedures in importing countries are added.

According to the conceptual framework, it is expected that OBOR increases the efficiency of trade facilitation. The efficiency of trade facilitation is measured in terms of time to comply export and import procedures. Log of exports is negatively related with both variables indicating that export is discouraged with longer time to comply with procedures. It is observed that the compliance time of exports has greater effect on trade $(-1.81)$ than the effect of import procedures (-0.81). All the coefficients of the models estimated can be interpreted as point elasticity coefficients.

${ }^{5}$ Variables with high VIF values are excluded from the model. 
Regulatory efficiency and Free Trade in SAARC: Implications on impacts of OBOR on SAARC Trade

Table 4.3: Gravity Model

\begin{tabular}{|c|c|c|c|c|c|c|c|c|c|}
\hline & \multicolumn{3}{|c|}{ Base Gravity } & \multicolumn{3}{|c|}{ Model 2} & \multicolumn{3}{|c|}{ Model 3} \\
\hline & Coef. & $\mathrm{T}$ & VIF & Coef. & $\mathrm{t}$ & VIF & Coef. & $\mathrm{t}$ & VIF \\
\hline log Distance & -1.35 & -4.53 & 1.63 & -1.79 & -6.12 & 1.80 & -1.22 & -4.06 & 2.17 \\
\hline log GDP (Partner Country) & 0.99 & 9.27 & 1.65 & 0.93 & 8.99 & 1.78 & 1.03 & 10.10 & 1.98 \\
\hline $\log$ GDP (Reporting Country) & 1.46 & 16.06 & 1.02 & 1.28 & 12.55 & 1.48 & 1.28 & 13.26 & 1.50 \\
\hline log of Time to comply with import regulations & & & & -0.81 & -3.24 & 1.38 & -0.93 & -3.65 & 1.63 \\
\hline Log of Time to comply with export regulations & & & & -1.81 & -3.55 & 1.50 & -2.58 & -4.62 & 2.05 \\
\hline Interactive terms of Time to import and SAARC & & & & & & & -0.37 & -0.79 & 20.34 \\
\hline Interactive term of Time to export and SAARC & & & & & & & 1.05 & 2.27 & 19.50 \\
\hline Constant & -41.45 & -12.18 & & -23.68 & -4.80 & & -28.68 & -5.74 & \\
\hline Adjusted R squared & 0.68 & & & 0.73 & & & 0.76 & & \\
\hline $\mathrm{F}$ & 103.71 & & & 76.55 & & & 65.65 & & \\
\hline Root MSE & 2.22 & & & 2.06 & & & 1.93 & & \\
\hline $\mathrm{N}$ & 143 & & & 143 & & & 143 & & \\
\hline
\end{tabular}

Source: Author 
FGS - CJMR Colombo Journal of Multi - Disciplinary Research

Following the conceptual framework, this suggests that the compliance time will decrease with OBOR through its investments in technological know-how and through efficient practices in harbor handling.

Interactive terms of SAARC with two compliance time variables are added to the model. This is to explore the difference of the OBOR impact on within SAARC trade and trade of SAARC with rest of the world. It is found that only the SAARC interactive term with export compliance time is statistically significant. Its positive sign (1.05) indicates that the effect of compliance time to export procedures is less for within SAARC trade than that for the trade with outside SAARC.

\section{Interpretation of Results}

Results of the gravity model estimated in Section 4 are fully consistent with the theoretical expectations of the principle of gravity by Newton. According to Newton gravity is greater when the objects are closer and larger in size. The adoption of Newton's gravity principle to international trade suggests that the countries located closer engage in trade than the distance countries and larger countries will have more trade. The Base Gravity model reported in Table 3 above is consistent with this theoretical expectation. Subsequent models are constructed such that the previous model is nested in the subsequent model. For example, Base Gravity model is nested in Model 2 and Model 2 is nested in Model 3. Adjusted $\mathrm{R}^{2}$ and $\mathrm{F}$ statistics reported in Table 3 under each model show that the addition of variables has improved the explanatory power of subsequent models significantly. These indicate that the proxy measures of OBOR effects on trade facilities and their interactive terms with a dummy representing SAARC countries have significant influence on the explanatory power of the gravity equation. 


\section{Regulatory efficiency and Free Trade in SAARC: Implications on impacts of OBOR on SAARC Trade}

Using Model 2, Table 4: summarizes the compliance time elasticity measures

Table 4: Elasticity measures of SAARC exports

\begin{tabular}{lcc}
\hline & Within SAARC & Outside SAARC \\
\hline Distance elasticity & -1.22 & -1.22 \\
Size elasticity: Reporting Country & 1.28 & 1.28 \\
Size elasticity: Partner Country & 1.03 & 1.03 \\
Compliance time to export & -1.53 & -2.58 \\
Compliance time to import & -0.93 & -0.93 \\
Total compliance time & -2.46 & -3.51 \\
\hline
\end{tabular}

Source: Own calculations using Regression results in Table 4.3

According to the elasticity coefficients reported in Table 4, each one percent increase (decrease) of distance between reporting (export) country and partner (import) country the trade is decreased (increased) by 1.22 percent $^{6}$.

Table 4 reports 2 size elasticity coefficients; reporting country and partner country. It is noted that the size elasticity of reporting (exporting) country is significantly greater than that of partner (importing) country; larger countries have greater potential of export as compared to the export potential of smaller countries.

When, compliance time for export procedures reduces (increases) by one percent, the trade within SAAR is decreased (increased) SAARC by 1.53 percent. The same will have 2.58 percent impact on SAARC trade with rest of the world. Total compliance time elasticity in the third row is estimated by adding the numbers in first two rows.

Each one percent increase (decrease) of compliance time for import procedures will decrease (increase) SAARC trade by 0.93 percent. This is equal for both within and outside trade with SAARC.

Assuming that the OBOR will reduce compliance time for trade, it is anticipated that the OBOR initiative will have positive impact on trade in the SAARC region. It is clearly noted that OBOR initiative will have larger impact on SAARC with outside SAARC countries than within SAARC trade. According to the last row of Table 4, each one

${ }^{6}$ When the distance elasticity coefficient was decomposed into two as within SAARC trade and outside SAARC trade it was found that the distance elasticity for within SAARC is greater than that for outside SAARC trade. 
FGS - CJMR Colombo Journal of Multi - Disciplinary Research

percent decrease of compliance time due to OBOR will increase within SAARC trade by 2.46 percent and SAARC trade with rest of the world by 3.51 percent.

\section{Summary and Conclusions}

Using the aggregate data available from World Bank Open data bases and World Integrated Trade Solution, this study estimated the gravity model to describe the export pattern of SAARC countries. Therefore the reporting countries are only SAARC countries. However, partner countries include all SAARC countries and other major partner countries.

Estimated results show that the distance between two countries has negative impact on trade. Country size measured in terms of GDP has positive effect on trade. It is also observed that the compliance time in both reporting country as well as the partner country has a significant influence on trade. Higher compliance time discourages trade.

Using interactive terms of SAARC dummy and compliance time variables it is clearly observed that the compliance time effect becomes higher when SAARC countries engage in export with rest of the world.

A key assumption of this exercise is that OBOR will reduce the compliance time. Therefore, it is concluded that the OBOR will increase exports from SAARC countries. Therefore, the main hypothesis of this exercise that OBOR enhances trade is accepted by this study.

\section{References}

Akhter, N., \& Ghani, E. (2010). Regional Integration in South Asia: An Analysis of Trade Flows Using the Gravity Model. The Pakistan Development Review, 49(2), 105-118. Retrieved from http://www.jstor.org/stable/41263356

Wilson, J., Mann, C., \& Otsuki. T. (2003). Trade Facilitation and Economic Development: A New Approach to Quantifying the Impact. The World Bank Economic Review, 17(3), 367-389. Retrieved from http://www.jstor.org/stable/3990246

Nanda, N. (2003). WTO and Trade Facilitation: Some Implications. Economic and Political Weekly, 38(26), 2622-2625. Retrieved from http://www.jstor.org/stable/4413724 


\section{Regulatory efficiency and Free Trade in SAARC: Implications on impacts of OBOR on SAARC Trade}

Helble, M., Mann, C., \& Wilson, J. (2012). Aid-for-trade facilitation. Review of World Economics

/ Weltwirtschaftliches Archiv, 148(2), 357-376. Retrieved from http://www.jstor.org/stable/41485799

Development Partnership Program for South Asia, (2009). Study on Intraregional Trade and Investment in South Asia. Retrieved from https://www.adb.org/publications/study-intraregionaltrade-and-investment-south-asia

Otsuki, T. \& Wilson, J.S. (2008). Regional Integration in South Asia: What Role for Trade Facilitation? Retrieved from https://www.researchgate.net/publication/23550422_Regional_integration_in_South_Asia_what_ role_for_trade_facilitation

Hunt, S., \& Morgan, R. (1995). The Comparative Advantage Theory of Competition. Journal of Marketing, 59(2), 1-15. doi:10.2307/1252069

Syropoulos, C. (1999). Customs Unions and Comparative Advantage. Oxford Economic Papers, 51(2), 239-266. Retrieved from http://www.jstor.org/stable/3488613

Widodo, T. (2009). Dynamic Comparative Advantages in the ASEAN 3. Journal of Economic Integration, 24(3), 505-529. Retrieved from http://www.jstor.org/stable/23001257

De Mel, D. (2011). Trade Facilitation Issues in South Asia, Sri Lanka: South Asia Centre for Policy Studies (SACEPS).

Pisani-Ferry, J., Röttgen, N., Sapir, A., ITucker, P., Guntram, B., \& Wolff1(2016). Europe after Brexit: A proposal for a continental partnership by [Embargoed until August 29, 19:00 CET]. Retrieved from http://bruegel.org/wp-content/uploads/2016/08/EU-UK-20160829-final-1.pdf

Ekanayake, E.M., Mukherjee, A. \& Veeramacheneni, B. (2010). Trade Blocks and the Gravity Model: A Study of Economic Integration among Asian Developing Countries. Journal of Economic Integration, 25(4), 627-643.

Banik, N. \& Gilbert, J. (2008). Regional Integration and Trade Costs in South Asia, Retrieved from https://www.adb.org/sites/default/files/publication/155982/adbi-wp127.pdf

Murphey, R. (1960). Economic Conflicts in South Asia. The Journal of Conflict Resolution, 4(1), 83-95. Retrieved from http://www.jstor.org/stable/172585

Tahir-Kheli, S. (1973). BILATERALISM IN SOUTH ASIA. World Affairs, 136(1), 74-87. Retrieved from http://www.jstor.org/stable/20671501 
FGS - CJMR Colombo Journal of Multi - Disciplinary Research

Shrestha, H., \& Upadhyay, M. (2004). Political Economy of Regional Trading Arrangements in South Asia. Journal of Economic Integration, 19(3), 427-446. Retrieved from http://www.jstor.org/stable/23000693

Batra, A. (2007). South Asia's Free Trade Agreement: Strategies and Options. Economic and Political Weekly, 42(38), 3878-3885. Retrieved from http://www.jstor.org/stable/40276424

Kelegama, S. (2007). Towards Greater Economic Connectivity in South Asia. Economic and Political Weekly, 42(39), 3911-3915. Retrieved from http://www.jstor.org/stable/40276463

De, P., \& Ghosh, B. (2008). Reassessing Transaction Costs of Trade at the India-Bangladesh Border. Economic and Political Weekly, 43(29), 69-79. Retrieved from http://www.jstor.org/stable/40277746

Din, M., \& Nasir, S. (2004). Regional Economic Integration in South Asia: The Way Forward. The Pakistan Development Review, 43(4), 959-974. Retrieved from http://www.jstor.org/stable/41261037

Batra, A. (2007). South Asia's Free Trade Agreement: Strategies and Options. Economic and Political Weekly, 42(38), 3878-3885. Retrieved from http://www.jstor.org/stable/40276424

Wilson, J., Mann, C., \& Tsunehiro Otsuki. (2003). Trade Facilitation and Economic Development: A New Approach to Quantifying the Impact. The World Bank Economic Review, 17(3), 367-389. Retrieved from http://www.jstor.org/stable/3990246

Nitya Nanda. (2003). WTO and Trade Facilitation: Some Implications. Economic and Political Weekly, 38(26), 2622-2625. Retrieved from http://www.jstor.org/stable/4413724

Globalization Backlash, SOUTH ASIA ECONOMIC FOCUS SPRING 2017. (2017). Washington, DC, USA: International Bank for Reconstruction and Development/World Bank. Retrieved from https://openknowledge.worldbank.org/bitstream/handle/10986/26373/9781464810954.pdf?seque nce $=5$ \&isAllowed $=\mathrm{y}$

Doing Business in South Asia 2007. (2007). Washington, DC, USA: International Bank for Reconstruction and Development/World Bank. Retrieved from http://www.doingbusiness.org/ /media/WBG/DoingBusiness/Documents/SubnationalReports/DB07-Sub-South-Asia.pdf

$\mathrm{Ng}$, A. (2015). Navigating the Belt and Road Financial sector paves the way for infrastructure. China: Ernst Young Global Limited. Retrieved from http://www.ey.com/Publication/vwLUAssets/EY-navigating-the-belt-and-road-en/\$FILE/EYnavigating-the-belt-and-road-en.pdf 


\section{Regulatory efficiency and Free Trade in SAARC: Implications on impacts of OBOR on SAARC Trade}

Ye, M. (2015). China and Competing Cooperation in Asia-Pacific: TPP, RCEP, and the New Silk Road. Asian Security, 11(3), 206-224. doi: 10.1080/14799855.2015.1109509

Len, C. (2015). China's 21st Century Maritime Silk Road Initiative, Energy Security and SLOC Access. Maritime Affairs: Journal of the National Maritime Foundation of India, 11(1), 1-18. doi:10.1080/09733159.2015.1025535

Summers, T. (2016). China's 'New Silk Roads': sub-national regions and networks of global political economy. Third World Quarterly, 37(9), 1628-1643. doi:10.1080/01436597.2016.1153415 